\title{
Theoretical Approach and Analysis of Stakeholders' Impact on Quality Processes in Higher Education - The Case of Greek Universities
}

\author{
Panagiota Xanthopoulou
}

\begin{abstract}
The issue of identifying and managing stakeholders has been largely explored by international literature and articles focusing on private sector organizations (Christopher et al., 2002; Rutterford et al., 2006), and the importance of this issue is also gradually increasing in public sector organizations (Maassen, 2000; Wit and Verhoeven, 2000; Peters, 1996; Kettle, 2002). However, less extensive research efforts have been observed in the application and analysis of stakeholder theory in public universities. Stakeholder recognition and management as well as the measurement and subsequent evaluation of their impact on quality service delivery are important in terms of effective management (Mitchell et al., 1997), strategic decision making and rational planning (Bryson, 2004), and by consistency in the application of the principles of Total Quality Management. Identifying and understanding the stakeholders related to an organization and the influence they have on the organization are crucial for managers and policy makers. The purpose of the present research is to explore the specific gap in the literature, that is, to understand the nature, needs and expectations of stakeholders, the satisfaction of which is a sufficient and necessary condition for the effective delivery of quality services at a University. In this context, the study focused on identifying stakeholders of a University as well as the degree of influence they have on providing quality educational services but also on the dropout rate of students, using case studies from two Greek Universities. Specifically, Panteion University of Social and Political Sciences has been selected as a foundation based on traditional, life-long teaching, and the Hellenic Open University, focusing on its undergraduate and postgraduate programs. In this way, a comparison is made of the quality criteria as perceived by the stakeholders of the two Universities with a different approach and philosophy of providing educational services.
\end{abstract}

Keywords: Higher Education, Stakeholders, Quality of Service, Quality in Education

\begin{abstract}
Introduction
Purpose and Research Questions: The purpose of the present study is to explore the specific gap in the literature, namely to understand the nature, the needs and expectations of stakeholders, the satisfaction of which is a sufficient and necessary condition for the effective delivery of quality services at a University. In this context, the study focuses on identifying the stakeholders of a University as well as the degree of influence they have on the provision of quality educational services as well as on the dropout rate of students, using case studies from two Greek Universities.

Based on the above purpose, the following individual objectives are achieved:

1. Identification of University stakeholders

2. Determining the degree of impact they have on the provision of quality services

3. Investigating and classifying the factors leading to student dropout
\end{abstract}

4. Investigating and recording the factors that most influence the provision of quality services by University stakeholders

5. Comparison of the above between a Traditional University and a University of Open and Distance Education.

Research questions:

1. What are the stakeholders of a university?

2. Which stakeholders have the greatest impact on the quality of service of a University

3. What factors influence the priorities of each stakeholder group

4. Which actions-strategic decisions have the greatest impact on the quality of educational services?

5. What factors influence students' dropout and commitment to a curriculum and consequently to their university?

The interpretation of the above objectives is attempted by exploring the meanings of the key

This article is published under the terms of the Creative Commons Attribution License 4.0 Author(s) retain the copyright of this article. Publication rights with Alkhaer Publications. Published at: http://www.ijsciences.com/pub/issue/2020-02/

DOI: 10.18483/ijSci.2269; Online ISSN: 2305-3925; Print ISSN: 2410-4477 
stakeholders in the educational process. This technique-methodology was chosen on the one hand because the meaning and understanding of those involved provides more and more qualitative information compared to an 'objective' imprint, as they make decisions and make choices, on the other hand because there are difficulties and complex issues arise. Finally, signifying quality-related issues will help to investigate the factors that determine the effectiveness of stakeholder performance and the consequences.

\section{Literature Review \\ The concept of quality on Higher Education}

It is worth mentioning that the concept of quality through the education and the analysis of stakeholders in education concern many researchers, and a model for quality in teaching and learning has not been formally established, especially in distance education (Ioakimidou, 2019). In addition, it is worth noting that stakeholder analysis mainly concern private sector organizations. It is therefore appropriate to explore the issue of this gap in the literature, from the perspective of stakeholders of a public university. ICTs have become increasingly prominent in today's age. The English translation of the term does not include the word "education", which means that educational technologies alone are not an educational tool. No technology application was born as an educational tool. It initially functions as a communication tool, which we design in such a way that it subsequently functions as an educator. Learning is a product that derives from the learner's personal motivation. Teaching, on the other hand, is influenced by all parties involved in a university. At this point, it is appropriate to investigate and record the views, impacts of the parties involved and their perception of quality, both during live teaching and distance learning, in order to avoid discontinuities and non-integration, and thus failure to ensure quality processes.

\section{Identification and categorization of stakeholders}

The term "stakeholders" may be applicable to a large number of groups and their management can prove to be complex. Therefore, identifying the stakeholders of the organization and their impact is important (Mitchell et al., 1997), as it can lead to the identification of a "profitable organization" (Bryson, 2004). Therefore, it is important to identify those areas that are important in different areas of strategic decision-making, and analyze their needs in order to form a Total Quality Management model within a University. However, it should be noted that the relative importance of each group may vary over time (Mitchell et al., 1997). It is clear from the literature on stakeholder management that understanding how different stakeholder groups differ in their importance is a vital issue (Gomes and Liddle, 2009). In this context, stakeholders can effectively represent opportunities or threats in an organization (Gomes and Liddle, 2009), depending on whether they are recognized and actively managed or not (Bryson, 2004). The variety of approaches to stakeholder analysis developed in the literature has undoubtedly created confusion as to what exactly is meant (Reed et al., 2009). Various factor-based classifications have been proposed such as whether stakeholders are voluntary or involuntary (Clarkson, 1995), on their level of authority and degree of interest (Johnson and Scholes, 2002) and participation (Reed, 2008). However, although these contexts are clearly relevant to the field of education, the factors that specifically influence the importance of a stakeholder group for universities have not been explored. While it is likely that some of the stakeholder groups identified for private sector organizations will also be relevant to universities, it is necessary to further explore this issue, in particular with regard to the unique nature of university activities and responsibilities in different groups. Indeed, universities are most likely to have a very complex environment of stakeholders, and therefore consideration of the environment and management of these factors is appropriate.

\section{Stakeholder Theories and Stakeholder Ranking}

Higher education institutions are vital for the development of nations. Higher education institutions, whose primary objective is the production and dissemination of knowledge, are concerned with the development of almost every aspect of life. Stakeholders somehow influence the creation and dissemination of knowledge, so it is important to identify the stakeholders of a university as they are influenced by the outcome of the university activities. Questions about who and what counts in an organization have attracted researchers' attention for decades. Business administration scholars, in particular, have developed the concept of stakeholder, referring to groups or individuals affected by the success or failure of an organization (Freeman, Harrison, Wicks, \& Colle, 2010). Higher education literature covers many categories of stakeholders, but does not provide a framework for identifying them (Burrows, 1999). Mitchell, Agle and Wood (1997) approach the concept of "stakeholders" in terms of management and business and state that the current literature does not meet the needs of identifying stakeholders in an organization. Individuals, groups, public, private and governmental organizations, institutions, societies, and the natural environment can all be bodies of an organization. Mitchell, Agle, and Wood (1997) focus on the relationship between the organization and stakeholders. According to Wicks et al. (1994) stakeholders have a relationship that adds value and 
meaning to the organization. There is a power relationship between the organizations involved. In situations where stakeholders are predominant, the organization is dependent on the stakeholders and therefore the parties exercise authority over the organization. The third rationale for researching the concept of stakeholder is to focus on the power relations between the organization and stakeholders. The difference between this and the second one is that in this case the organization is dominant and the stakeholders depend on the organizations. The next reason for stakeholder research is to identify stakeholders and their ability to influence the functioning of the organization, which refers to the reciprocal dependency of the organization and stakeholders. The fifth reason for stakeholder research is that the organization and stakeholders have a contractual relationship. In this respect, the latter have a claim on the organizations and may benefit or be harmed by the activities of the former. Among the various definitions of stakeholders, Freeman's (1984) approach is the most widely cited in the literature (Mitchell, Agle, \& Wood, 1997). Freeman (1984) states that "a stakeholder in an organization is (by definition) any group or individual that may be influenced or affected by the achievement of the goals of the organization" (p. 46). However, it should be noted that no definition is universally accepted (Mitchell, Agle, \& Wood, 1997). Mitchell, Agle and Wood (1997) argue that the key concepts in organization theories that seek to identify stakeholders are 'power' and 'legitimacy'. However, power and legitimacy are considered competing concepts of stakeholders. The key conceptual approaches to stakeholder main theories are practice, behavior, institutional, population dependency, resource dependency and transaction costs. Agency theory suggests that managers must control the behavior of their agents in order to accomplish the goals of the organization. This can be achieved through motivation and monitoring. Resource dependence theory shows that stakeholders have resources and therefore have authority over the organization. Transaction cost theory suggests that stakeholders who are not internal to the organization and participate in a very small competitive pool can "increase transaction costs to levels justifying their absorption in the business" (Mitchell, Agle , \& Wood, p. 863, 1997). These theories suggest that power relations between managers and stakeholders are very important elements of stakeholder theory. However, focusing exclusively on power does not help identify stakeholders. Institutional and population theories link organizational legitimacy to the existence of organization. According to these theories, it is the legal stakeholders that really matter. However, too much emphasis on legitimacy can lead to a breach of power relations. "Urgency" is the last characteristic that affects leaders' perceptions of stakeholders. Urgency is defined by the authors as "the extent to which interested parties seek immediate attention" (p. 867). Although the urgency is a view that is not explicitly structured in the theories of those concerned, it is implicitly present. According to the theory of behavior, urgency corresponds to unfulfilled goals.

Figure. 1. The SARM Stakeholder Model

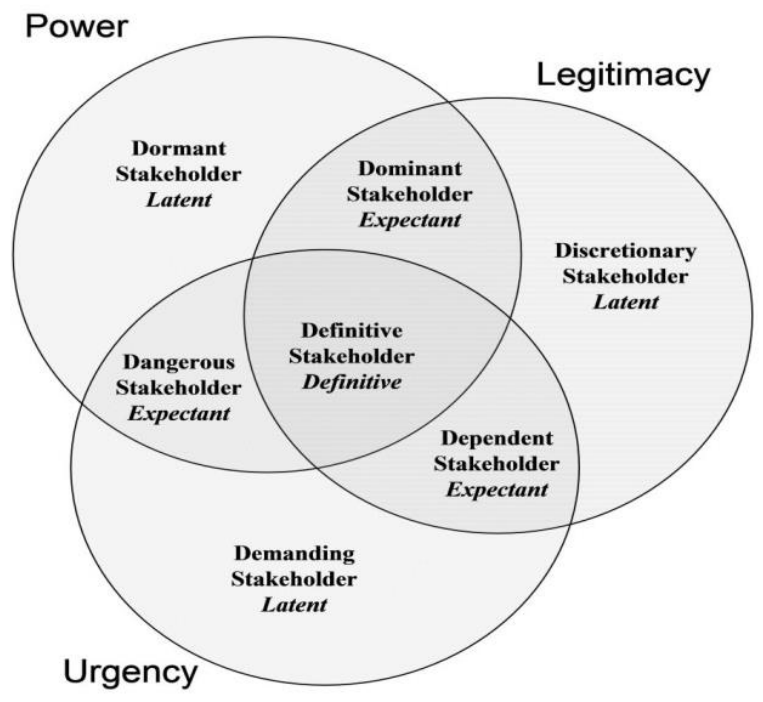

source: Mitchell, Agle \& Wood, Academy of Management Review Vo. 22, No. 4, p874

\section{Categories of interested higher education institutions}

According to Birnbaum (1988) "Learning how colleges and universities work requires us to see them as organizations, systems and inventions" (p. 2). Another way to find out how colleges and universities work is to know the stakeholders. Knowing who the stakeholders are and why they are interested can greatly help higher education managers understand and operate their work and the institution. Burrows (1991) notes that the use of categories instead of groups expands our rationale for how we view future stakeholders. Burrows (1991) includes the following categories of higher education stakeholders: Government agencies, administration, employees, customers, suppliers, competitors, donors, communities, government regulators, nongovernmental regulators, financial intermediaries and financial intermediaries. The investigation of all interested parties goes beyond the scope of this investigation. The literature is abundant with the categories of stakeholders and their most important features. However, there is still confusion as to how to identify stakeholders, particularly in the field of higher education. The two stakeholder approaches discussed in this section are the Burrows' (1999) approach and Mitchell, Agle, \& Wood's (1997) 
theory of stakeholder identification. Burrows (1999) proposes a useful framework for classifying stakeholders into higher education institutions. According to her, stakeholder recognition is important, however, not enough to understand and prioritize stakeholder demands. Thus, he proposes multiple factors that would serve to distinguish stakeholders (Burrows, 1999). The four lenses are based on location (external and internal stakeholders), participation status (active and passive stakeholders), cooperation and threat potential, and stakeholder involvement and influence in the institution. The external and internal stakeholder category is the most common form, but it does not always help with stakeholder groups in academia. For example, university students can be viewed as external factors from the perspective of enrollment. However, they can be considered as internal stakeholders as they have an impact on the academic work carried out at the university. Active stakeholders are the individuals or groups who actively participate in the institution. On the other hand, the passive actors of higher education institutions are those who have no legal, financial or ethical relationship with the institution, but have been affected by past actions or may be affected by the institution's future actions. Going through the literature, the stakeholder model (Figure 1) of Mitchell et al. (1997) offers an alternative structure for framing and classifying stakeholders according to the management conceptions of stakeholder characteristics. The model assumes that executives should make decisions about stakeholder involvement, on the credibility of stakeholders. This evaluation is supported (Mitchell et al., 1997) should be based on consideration of the authority of the parties concerned and the urgency and the legality of their claims. It has been recognized (Klijn, Koppenjan, \& Termeer, 1995) that this power and legitimacy can influence who will be included in a network and, therefore, the network structure, rules of network participation, and the results achieved. Therefore, it could be argued that the stakeholder salience model (Mitchell et al., 1997) provides a highly relevant framework for theorizing how stakeholders are involved in governance networks. The model incorporates three variables: power, urgency, legitimacy (power, urgency, legitimacy) that concentrate on constructing the conceptual meaning of the stakeholders. In this model, Mitchell et al. (1997, p. 865) have suggested that power is the ability of stakeholders to achieve the desired results and comes from three dimensions: normative, coercive and utilitarian. While regulatory power is demonstrated through the use of symbolic resources such as media attention, coercive power comes from the application of natural resources including containment or force (Friedman and Miles, 2006).
The final dimension, utility power, is "the use of material means for (Ejioni, 1964, p. 59) and is exercised through the control of resources, particularly financial. The second variable in the model, 'urgency' is determined by the time sensitivity of the stakeholder demand and the criticality or perceived importance of their claim (Mitchell et al., 1997). In this context, the urgency implies a changing balance of power in the relationship as a result of the perceptions that are critical to a particular stakeholder claim of the organization and that their claim requires immediate attention from the organization. Mitchell et al. (1997) continue to define urgent issues as a single dimension, "the extent to which stakeholder demands call for immediate attention". However, it could be argued that criticality and timeliness are discrete variables indicating the importance and timeliness and therefore need to be measured in different ways. It could also be argued that treating criticality and timeliness as discrete variables in determining the importance of stakeholders would produce additional and different configurations to those provided by Mitchell et al. (1997). The third variable in the model, legitimacy, is defined as "the generalized perception or assumption that an entity's actions are desirable, appropriate within some socially constructed system of rules, values, beliefs and definitions" (Suchman, 1995, p. 574). It has been argued that the legitimacy of stakeholders can be either regulatory: fulfilling legal or ethical obligations (Gomes and Gomes, 2007) or derivative: resulting from organizational acceptance of stakeholder demands due to their potential impact (Phillips, 2003). Mitchell, Agle, \& Wood (1997) define power as the degree to which a group has or can access material means, utilities, or norms (prestige, esteem, etc.) to enforce their will (p.869). "legitimacy" refers to the actions of an organization that are desirable and appropriate to society's rules, beliefs and values. "Urgency" is the concept that refers to the stakeholder demand for immediate attention. The "degree" of urgency depends not only on the sensitivity of time but also on how "critical" is the relationship with the person concerned or the importance of their claim. All three concepts of power, legitimacy and urgency are socially constructed phenomena. The increased importance of these three factors increases the value of the stakeholders. In other words, the highest priority will be given to those concerned with authority, legitimacy and urgency. Power and legality are interrelated and the three variables can overlap 


\section{Research Methodology}

Valid and reliable results for each research can only be obtained by the appropriate combination of quantitative and qualitative methods, in order to avoid overestimation or over-simplification (Leiber, Stensaker, \& Harvey, 2015: 295). Quantitative data can give an overview and some trends, while qualitative data provide details (McBeath, 2001: 152). Positions and opinions about the experience of the learning process and its quality at a university can best be documented through qualitative and quantitative data (Hamshire, Forsyth, Bell, Benton, Kelly-Laubscher, Paxton, \& Wolfgramm-Foliaki, 2017). Investigating signaling requires a variety of research methods combined with quantitative and qualitative measurements in order to highlight the experience itself and factors related to its various aspects, for example through questionnaires and interviews with not only students but teachers and other stakeholders (Tam, 2001: 53). However, a single tool cannot meet the expectations of the research, it requires the use of a variety of consciously selected and designed tools that can sometimes even overlap if quality is to be ensured in complex and multi-level fields (Beerkens, 2015: 245). The present study selects a mixed-type approach that combines alternative approaches (Denscombe, 2008) because large-scale quantitative research can identify valid and reliable trends and orientations that can then in-depth investigate quality approaches. The approach to the topic is descriptive (Cohen \& Manion, 1997). Specifically, the method of bibliographic review was used, the aim of which was "to seek objectivity with a view to minimizing distortions and ... to describe all aspects of the particular situation under consideration" (Cohen \& Manion, 1997, pp. 70-71). The present research falls under the category of flexible research projects since during its preparation it has often been necessary to refine research questions, the research method, data collection techniques, and even the problem itself with new data and issues emerging in the process.

\section{Results}

The following analysis refers to the collection of 83 questionnaires that were answered by 35 professors and / or administrative staff of Greek universities as well as by 48 Greek university students.

\begin{tabular}{|l|r|r|r|r|}
\hline \multicolumn{7}{|c|}{ Item-Total Statistics } \\
\hline Q1 & $\begin{array}{c}\text { Scale Mean if } \\
\text { Item Deleted }\end{array}$ & $\begin{array}{c}\text { Scale } \\
\text { Variance if } \\
\text { Item Deleted }\end{array}$ & $\begin{array}{c}\text { Corrected } \\
\text { Item-Total } \\
\text { Correlation }\end{array}$ & $\begin{array}{c}\text { Cronbach's } \\
\text { Alpha if Item } \\
\text { Deleted }\end{array}$ \\
Q3 & 37,73 & 123,490 &, 744 &, 889 \\
Q4 & 36,73 & 138,002 &, 065 &, 908 \\
Q5 & 37,36 & 127,380 &, 499 &, 896 \\
Q6 & 37,73 & 122,953 &, 661 &, 891 \\
Q7 & 37,39 & 122,240 &, 698 &, 890 \\
Q8 & 37,49 & 124,180 &, 553 &, 895 \\
Q9 & 37,20 & 128,506 &, 493 &, 896 \\
Q10 & 37,55 & 124,177 &, 645 &, 892 \\
Q11 & 37,49 & 124,326 &, 617 &, 893 \\
Q12 & 37,71 & 120,159 &, 712 &, 889 \\
Q13 & 37,75 & 124,679 &, 681 &, 891 \\
Q14 & 37,77 & 123,057 &, 619 &, 892 \\
Q15 & 37,58 & 124,954 &, 548 &, 895 \\
Q16 & 37,64 & 123,721 &, 683 &, 891 \\
Q17 & 37,28 & 127,837 &, 461 &, 897 \\
Q18 & 37,20 & 129,165 &, 413 &, 899 \\
\hline
\end{tabular}

Table 1. Questionnaire reliability

Reliability Statistics

\begin{tabular}{|r|r|}
\hline $\begin{array}{c}\text { Cronbach's } \\
\text { Alpha }\end{array}$ & N of Items \\
\hline, 900 & 18 \\
\hline
\end{tabular}

Reliability Statistics

\begin{tabular}{|r|r|}
\hline $\begin{array}{c}\text { Cronbach's } \\
\text { Alpha }\end{array}$ & N of ltems \\
\hline, 797 & 21 \\
\hline
\end{tabular}


Item-Total Statistics

\begin{tabular}{|l|r|r|r|r|}
\hline & $\begin{array}{c}\text { Scale Mean if } \\
\text { Item Deleted }\end{array}$ & $\begin{array}{c}\text { Scale } \\
\text { Variance if } \\
\text { Item Deleted }\end{array}$ & $\begin{array}{c}\text { Corrected } \\
\text { Item-Total } \\
\text { Correlation }\end{array}$ & $\begin{array}{c}\text { Cronbach's } \\
\text { Alpha if Item } \\
\text { Deleted }\end{array}$ \\
\hline Q1 & 43,53 & 123,520 &, 713 &, 774 \\
Q3 & 42,53 & 137,472 &, 061 &, 802 \\
Q4 & 43,16 & 126,743 &, 500 &, 782 \\
Q5 & 43,53 & 122,935 &, 636 &, 775 \\
Q6 & 43,18 & 121,565 &, 702 &, 771 \\
Q7 & 43,29 & 124,769 &, 506 &, 781 \\
Q8 & 43,00 & 128,024 &, 487 &, 784 \\
Q9 & 43,35 & 124,108 &, 622 &, 776 \\
Q10 & 43,29 & 124,013 &, 605 &, 777 \\
Q11 & 43,51 & 120,546 &, 673 &, 771 \\
Q12 & 43,54 & 124,349 &, 668 &, 775 \\
Q13 & 43,57 & 121,858 &, 645 &, 773 \\
Q14 & 43,37 & 124,895 &, 526 &, 780 \\
Q15 & 43,43 & 124,224 &, 632 &, 776 \\
Q16 & 43,07 & 127,726 &, 440 &, 785 \\
Q17 & 43,00 & 128,829 &, 402 &, 787 \\
Q18 & 43,19 & 128,597 &, 387 &, 787 \\
Q19 & 43,24 & 130,673 &, 320 &, 791 \\
Q20 & 44,01 & 139,280 &, 022 &, 800 \\
Q21a & 43,28 & 146,520 &,- 216 &, 873 \\
& 43,33 & 139,027 &,- 065 &, 826 \\
\hline
\end{tabular}

The resulting percentage corresponds to $90 \%$ Reliable to be above 0.7 . To check the reliability of the questionnaire as to whether it measures the variable - those it intends to measure, there is a Cronbach's Aplha coefficient which indicates the reliability of the primary data collection tool. According to Taber (2017) the questionnaire should receive Gronbach's Alpha values of $>0.7$ to demonstrate reliability. Looking at Table 1 we see that the questionnaire has a reliability index of 0.9 which is well above the $70 \%$ threshold. Therefore, the reliability of the questionnaire has been accredited. Also, Table 2 shows individually the reliability of each query where all the questions indicate to have a reliability level of at least 0.89 , which individually indicates the reliability of the data collection tool.

\section{Table 2. Highly influential parties in the services of} Greek universities

One-Sample Statistics

\begin{tabular}{|l|r|r|r|r|}
\hline & $N$ & Mean & Std. Deviation & \multicolumn{1}{c|}{$\begin{array}{c}\text { Std. Error } \\
\text { Mean }\end{array}$} \\
\hline Q1 & 83 & 1,94 &, 967 &, 106 \\
Q2 & 83 & 2,94 &, 967 &, 106 \\
Q3 & 83 & 2,31 & 1,058 &, 116 \\
Q4 & 83 & 1,94 & 1,108 &, 122 \\
\hline
\end{tabular}

One-Sample Test

\begin{tabular}{|c|c|c|c|c|c|c|}
\hline & \multicolumn{6}{|c|}{ Test Value $=0$} \\
\hline & \multirow[b]{2}{*}{$t$} & \multirow[b]{2}{*}{ df } & \multirow[b]{2}{*}{ Sig. (2-tailed) } & \multirow{2}{*}{$\begin{array}{c}\text { Mean } \\
\text { Difference }\end{array}$} & \multicolumn{2}{|c|}{$\begin{array}{l}\text { 95\% Confidence Interval of the } \\
\text { Difference }\end{array}$} \\
\hline & & & & & Lower & Upper \\
\hline Q1 & 18,273 & 82 & .000 & 1,940 & 1,73 & 2,15 \\
\hline Q2 & 27,693 & 82 &, 000 & 2,940 & 2,73 & 3,15 \\
\hline Q3 & 19,912 & 82 &, 000 & 2,313 & 2,08 & 2,54 \\
\hline Q4 & 15,947 & 82 & .000 & 1,940 & 1,70 & 2,18 \\
\hline
\end{tabular}

This section analyzes descriptive and inferential statistics using mean values (negative averages) as well as confidence intervals for the mean value of each question at $95 \%$ level. The first four questions show measurements of which member of the academic community has a greater influence on the quality of University services, which are: (a) University Management, (b) Student Associations, (c) Administrative staff and other researchers. The responses to these four parts indicate that University administration and research / teaching staff appear to have the greatest impact on services to the same degree with an average value of 1.94 , which is very close to '2' (' Agree"). 95\% confidence intervals were used to derive the mean values. They are also followed by the administrative staff with a mean of 2.31, which is closer to agreement on its impact. Last in impact comes a section on student associations which are close to the 'neutral' value. Confidence intervals confirm with a $95 \%$ probability that management tends to be the most influential party as the average value ranges between 1.73 and 2.15 which is close to 2 ("I agree"). Very close are the teaching / research staff with 2.18. Regarding student associations and their impact, it appears to be in the free zone as it has a trading interval around the neutral value of "3", with 2.73 to 3.15 intervals. Finally, administrative staff show intervals of 2.08 2.54 where they are closer to the value of "2" where they indicate that they have an impact on quality services. The same questions were also analyzed to determine if there were significant differences between students and staff at the University. Concerning the impact of administration, university staff seems to agree more on the influence of administrative staff on quality processes than 
students. Regarding the impact of student associations on the quality of University processes, both parties tend to show that the impact of student associations is neutral, which may mean that their impact is low.

Table 3. Factors Affecting Stakeholders in Quality Assurance Procedures of Greek Universities

The next 5 questions refer to factors that may influence the assurance of quality processes in Greek universities such as remuneration, employment status, decision-making through colleges, logistics and synergies along with the adoption of best practices from outside institutions.

One-Sample Statistics

\begin{tabular}{|l|r|r|r|r|}
\hline & $N$ & Mean & Std. Deviation & \multicolumn{1}{c|}{$\begin{array}{c}\text { Std. Error } \\
\text { Mean }\end{array}$} \\
\hline Q5 & 83 & 2,29 & 1,099 &, 121 \\
Q6 & 83 & 2,18 & 1,201 &, 132 \\
Q7 & 83 & 2,47 &, 980 &, 108 \\
Q8 & 83 & 2,12 & 1,052 &, 116 \\
Q9 & 83 & 2,18 & 1,084 &, 119 \\
\hline
\end{tabular}

One-Sample Test

\begin{tabular}{|c|c|c|c|c|c|c|}
\hline & \multicolumn{6}{|c|}{ Test Value $=0$} \\
\hline & \multirow[b]{2}{*}{$t$} & \multirow[b]{2}{*}{ df } & \multirow[b]{2}{*}{ Sig. (2-tailed) } & \multirow{2}{*}{$\begin{array}{c}\text { Mean } \\
\text { Difference }\end{array}$} & \multicolumn{2}{|c|}{$\begin{array}{l}\text { 95\% Confidence Interval of the } \\
\text { Difference }\end{array}$} \\
\hline & & & & & Lower & Upper \\
\hline$\overline{Q 5}$ & 18,975 & 82 &, 000 & 2,289 & 2,05 & 2,53 \\
\hline Q6 & 16,541 & 82 &, 000 & 2,181 & 1,92 & 2,44 \\
\hline Q7 & 22,972 & 82 &, 000 & 2,470 & 2,26 & 2,68 \\
\hline Q8 & 18,359 & 82 &, 000 & 2,120 & 1,89 & 2,35 \\
\hline Q9 & 18,334 & 82 &, 000 & 2,181 & 1,94 & 2,42 \\
\hline
\end{tabular}

The two tables above contain mean values for each of the five factors as well as confidence intervals of the mean values to conclude with these $95 \%$ probability averages. Respondents tended to show greater agreement as a factor in ensuring quality processes for logistical infrastructure (explanation) with a mean of 2.12 and a confidence interval of 1.89-2.35. Following are figures with figures of 2.18 on employment status (explanation) and synergies with best practices from overseas institutions. Although these 2 factors have the same values, the employment status appears to be closer to the value of 2 (I agree) with a lower average value of 1.92 and 1.94 for foreign universities synergies and best practices. The two remaining factors which are pay and participation in decision making through collective bodies with average values of 2.29 and 2.47 yes are in the area of "2" but their average price ceilings are above 2.5 approaching the neutral area. Analyzing the responses by gender, it appears that men tend to agree more than women on the "logistical" and "employment status" factor.

Table 4. Actions / decisions that have the greatest impact on the quality of educational services of Greek universities This set of questions analyzes what actions - strategic decisions affect the quality of educational services.

\begin{tabular}{|l|r|r|r|r|}
\multicolumn{7}{|c|}{ One-Sample Statistics } \\
\hline & $\mathrm{N}$ & Mean & Std. Deviation & $\begin{array}{c}\text { Std. Error } \\
\text { Mean }\end{array}$ \\
\hline Q10 & 83 & 1,96 & 1,204 &, 132 \\
Q11 & 83 & 1,93 &, 973 &, 107 \\
Q12 & 83 & 1,90 & 1,165 &, 128 \\
Q13 & 83 & 2,10 & 1,154 &, 127 \\
\hline
\end{tabular}

One-Sample Test

\begin{tabular}{|c|c|c|c|c|c|c|}
\hline & \multicolumn{6}{|c|}{ Test Value $=0$} \\
\hline & \multirow[b]{2}{*}{$t$} & \multirow[b]{2}{*}{ df } & \multirow[b]{2}{*}{ Sig. (2-tailed) } & \multirow{2}{*}{$\begin{array}{l}\text { Mean } \\
\text { Difference }\end{array}$} & \multicolumn{2}{|c|}{$\begin{array}{l}95 \% \text { Confidence Interval of the } \\
\text { Difference }\end{array}$} \\
\hline & & & & & Lower & Upper \\
\hline Q10 & 14,859 & 82 &, 000 & 1,964 & 1,70 & 2,23 \\
\hline Q11 & 18,057 & 82 &, 000 & 1,928 & 1,72 & 2,14 \\
\hline Q12 & 14,891 & 82 &, 000 & 1,904 & 1,65 & 2,16 \\
\hline Q13 & 16,548 & 82 &, 000 & 2,096 & 1,84 & 2,35 \\
\hline
\end{tabular}


Responses indicate that curriculum reform is being reworked based on new working and educational conditions as a major influence on the quality of educational services. The mean ranged from 1.9 with a confidence interval of 1.65 to 2.16 . We can therefore conclude that there is agreement on actions that upgrade university programs that take into account new market conditions and academic infrastructure. Also, collaborations with other programs and universities as well as the scientific activity of the teaching staff appear to be important actions in terms of quality of educational services with average values of 1.93 and 1.96 respectively. Also, the confidence intervals of these two actions range from 1.72 to 2.14 and 1.70 to 2.23 respectively, which indicate a trend that is very close to value 2 (I agree). A short distance from the other 3 actions is the development and delivery of modern educational programs for students and professionals with an average value of 2.10 and a confidence interval of 1.84 to 2.35 which indicates that it is in general an important strategic part in creating quality educational services. In terms of analyzing genderbased responses, men seem to believe a little more than women about the impact of actions on the teaching staff's scientific activity and on curriculum reform based on new work and academic conditions.

Table 5. Factors affecting students' commitment to or abandonment of Greek university studies

The last set of questions concerns the factors that influence students' commitment to or abandonment of Greek university studies.

One-Sample Statistics

\begin{tabular}{|l|r|r|r|r|}
\hline & $N$ & Mean & Std. Deviation & \multicolumn{1}{c|}{$\begin{array}{c}\text { Std. Error } \\
\text { Mean }\end{array}$} \\
\hline Q14 & 83 & 2,04 & 1,029 &, 113 \\
Q15 & 83 & 2,40 & 1,093 &, 120 \\
Q16 & 83 & 2,47 & 1,075 &, 118 \\
Q17 & 83 & 2,28 & 1,130 &, 124 \\
Q18 & 83 & 2,23 & 1,086 &, 119 \\
\hline
\end{tabular}

One-Sample Test

\begin{tabular}{|c|c|c|c|c|c|c|}
\hline & \multicolumn{6}{|c|}{ Test Value $=0$} \\
\hline & \multirow[b]{2}{*}{$t$} & \multirow[b]{2}{*}{ df } & \multirow[b]{2}{*}{ Sig. (2-tailed) } & \multirow{2}{*}{$\begin{array}{c}\text { Mean } \\
\text { Difference }\end{array}$} & \multicolumn{2}{|c|}{$\begin{array}{l}\text { 95\% Confidence Interval of the } \\
\text { Difference }\end{array}$} \\
\hline & & & & & Lower & Upper \\
\hline Q14 & 18,020 & 82 &, 000 & 2,036 & 1,81 & 2,26 \\
\hline Q15 & 19,993 & 82 &, 000 & 2,398 & 2,16 & 2,64 \\
\hline Q16 & 20,941 & 82 &, 000 & 2,470 & 2,24 & 2,70 \\
\hline Q17 & 18,366 & 82 &, 000 & 2,277 & 2,03 & 2,52 \\
\hline Q18 & 18,704 & 82 &, 000 & 2,229 & 1,99 & 2,47 \\
\hline
\end{tabular}

According to the above statistics, students appear to be affected by a lack of personal motivation and an outdated curriculum, factors that contribute to their abandonment or commitment to their studies. These two factors are averaged 2.04 and 2.23 respectively, indicating agreement. The corresponding confidence intervals obtain values for the first factor 1.81-2.26 and for the second factor 1.99-2.47. Other factors such as the university environment and students' work commitments appear to be factors in student dropout but to a lesser extent for the two reasons cited above.

Table 6. Respondents' demographics

Q19

\begin{tabular}{|ll|r|r|r|r|}
\hline & Frequency & Percent & Valid Percent & $\begin{array}{c}\text { Cumulative } \\
\text { Percent }\end{array}$ \\
\hline Valid & Male & 45 & 54,2 & 54,2 & 54,2 \\
& Female & 38 & 45,8 & 45,8 & 100,0 \\
& Total & 83 & 100,0 & 100,0 & \\
\hline
\end{tabular}

Q20

\begin{tabular}{|c|c|c|c|c|c|}
\hline & & Frequency & Percent & Valid Percent & $\begin{array}{c}\text { Cumulative } \\
\text { Percent }\end{array}$ \\
\hline \multirow[t]{15}{*}{ Valid } & Public Admin-Panteion & 62 & 74,7 & 74,7 & 74,7 \\
\hline & Bus Mgnt-EAP & 9 & 10,8 & 10,8 & 85,5 \\
\hline & TEFAA & 1 & 1,2 & 1,2 & 86,7 \\
\hline & Aegean & 1 & 1,2 & 1,2 & 88,0 \\
\hline & Humanities-EAP & 1 & 1,2 & 1,2 & 89,2 \\
\hline & European Cultures-EAP & 1 & 1,2 & 1,2 & 90,4 \\
\hline & Library Sciences-EAP & 1 & 1,2 & 1,2 & 91,6 \\
\hline & Adolescent Learning-EAP & 1 & 1,2 & 1,2 & 92,8 \\
\hline & History/Archeol-Aristotelio & 1 & 1,2 & 1,2 & 94,0 \\
\hline & $\begin{array}{l}\text { Social Sciences- } \\
\text { Dimokritio }\end{array}$ & 1 & 1,2 & 1,2 & 95,2 \\
\hline & Univ. of Piraeus & 1 & 1,2 & 1,2 & 96,4 \\
\hline & $\begin{array}{l}\text { Political \& Social } \\
\text { Sciences }\end{array}$ & 1 & 1,2 & 1,2 & 97,6 \\
\hline & $\begin{array}{l}\text { Intern. \& European } \\
\text { Studies }\end{array}$ & 1 & 1,2 & 1,2 & 98,8 \\
\hline & Tourism Mgnt-Patras & 1 & 1,2 & 1,2 & 100,0 \\
\hline & Total & 83 & 100,0 & 100,0 & \\
\hline
\end{tabular}




\begin{tabular}{|c|c|c|c|c|c|}
\hline \multicolumn{6}{|c|}{ Q21a } \\
\hline & & Frequency & Percent & Valid Percent & $\begin{array}{c}\text { Cumulative } \\
\text { Percent }\end{array}$ \\
\hline \multirow[t]{6}{*}{ Valid } & University lecturer/staff & 35 & 42,2 & 42,2 & 42,2 \\
\hline & Student yr 2 & 3 & 3,6 & 3,6 & 45,8 \\
\hline & Student yr 3 & 14 & 16,9 & 16,9 & 62,7 \\
\hline & Student yr 4 & 25 & 30,1 & 30,1 & 92,8 \\
\hline & Student Master & 6 & 7,2 & 7,2 & 100,0 \\
\hline & Total & 83 & 100,0 & 100,0 & \\
\hline
\end{tabular}

\begin{tabular}{|c|c|c|c|c|c|}
\hline \multicolumn{6}{|c|}{ Q21b } \\
\hline & & Frequency & Percent & Valid Percent & $\begin{array}{c}\text { Cumulative } \\
\text { Percent }\end{array}$ \\
\hline \multirow[t]{3}{*}{ Valid } & University lecturer/staff & 35 & 42,2 & 42,2 & 42,2 \\
\hline & Student & 48 & 57,8 & 57,8 & 100,0 \\
\hline & Total & 83 & 100,0 & 100,0 & \\
\hline
\end{tabular}

\section{DISCUSSION OF RESULTS / CONCLUSIONS}

RQ1. The study of international literature reveals several theoretical approaches to the concept of stakeholders. The key question in higher education research is first to identify who the customer is, in order to then study the implementation of customercentric quality. Higher education literature covers many categories of stakeholders, but does not provide a framework for identifying them and identifying them (Burrows, 1999). Mitchell, Agle and Wood (1997) approach the concept of 'stakeholders' in terms of management and business and state that the current literature does not meet the needs of identifying stakeholders in an organization. The identification of stakeholders seems to support the essence of stakeholder management and is therefore the first area of research for the study. In this context, the aforementioned researchers discuss the need for a theory of stakeholder identification, which can reliably separate stakeholders from non-stakeholders, as each group will exist within a complex network of interactive relationships (Rowley, 1997). Therefore, stakeholders should be systematically represented (Wood, 2008). While it may be possible to promote the common interest of a stakeholder group through a specific strategy, the needs of the groups may be contradictory (Oliver, 1991). Undoubtedly, this can be even more so in the case of the university, as universities are involved in such a variety of activities and have public responsibility.

RQ2. It is evident that organizations typically have a wide variety of stakeholders and they compete with one another (Neville \& Menguc, 2006), leading managers to identify body management strategies (Gomes \& Gomes, 2009). Therefore, are not all stakeholders equally important (Freeman, 1984). It has become clear from the literature that understanding how different stakeholder groups differ in their importance is an important issue (Gomes and Liddle 2009). In this context, stakeholders can effectively represent opportunities or threats in an organization (Gomes and Liddle
2009), depending on whether they are recognized and actively managed or not (Bryson 2004). The external and internal stakeholder category is the most common form, but it does not always help with stakeholder groups in academia. Based on the answers given by the research participants, the first four questions show measurements of which member of the academic community has a greater influence on the quality of University services. The results confirm the theory developed by Mitchell, Agle, \& Wood (1997) as the greatest effect appears at the levels where there is a greater degree of authority and legitimacy, but also the Burrows theory, as the highest percentages of influence are identified in the active stakeholders, while the lower, in institutions that are passively involved in the institution and have no legal, financial or ethical relations with the institution (e.g. student associations).

RQ3. Emotional commitment of students to the university plays a central role in traditional educational research on student commitment. According to Tinto $(1975,1993)$, a student's commitment is largely determined by his or her degree of integration into the academic community. This integration can be achieved in two ways: first, through active participation in university societies and committees (i.e. academic integration), and second, through friendships and acquaintances with fellow students (i.e. social inclusion). Tinto argues that a higher degree of student integration into the university system leads to increased loyalty. In the RQSL model, student commitment is directly determined by three complex structures: students 'perceptions of the quality of teaching activities (or quality of service), students' trust in the institution's staff, commitment to the institution. Attraction, student satisfaction, and retention are closely related concepts. In addition, student satisfaction has become an extremely important issue for universities and their management. On the students' side, perceptions of educational quality have been found to be positively correlated with their satisfaction, so it makes sense to try to understand whether there is a relationship between employee satisfaction that results in higher quality in the educational experience. With regard to employees, as the second important stakeholder group analyzed, the theory converges that the common factors of higher education worker satisfaction are the job satisfaction, motivation and ethics they acquire, communication, training and development opportunities, their own perception of quality of service as well as their interactions with colleagues and their own ethos. Perkins (1973) suggested that university professors fulfill three major functions: teaching, research and management. Consequently, teacher satisfaction is related to the functions and outcomes of education. 
Lee (1988) has shown that job satisfaction is one of the best predictors of turnover. It also affects customer perceptions of the quality of service provided (Rafaeli, 1989; Schneider and Bowen, 1985). Indirect costs associated with job dissatisfaction include inadequate training as well as an increase in unreasonable decisions (Brown and Mitchell, 1993). Indeed, the responses to the survey questionnaire have shown that with numerical means values of 2.18 the employment status (explanation) and synergies with best practices from overseas institutions are important factors in ensuring quality processes. The remaining factors which are remuneration and participation in decision making through colleges with mean values of 2.29 and 2.47 yes are in the range of ' 2 ' but their average price ceilings are above the 2.5 approaching the neutral area. Analyzing the responses by gender, it appears that men tend to agree more than women on the "logistical" and "employment status" factor.

RQ4. Respondents' responses indicate that curriculum reform is being reworked based on new working and educational conditions as a major influence on the quality of educational services. We can therefore conclude that there is agreement on actions that upgrade university programs that take into account new market conditions and academic infrastructure. In addition, collaborations with other programs and universities as well as the scientific activity of teaching staff appear to be important actions in terms of the quality of educational services. A short distance from the other three activities is the development and delivery of modern educational programs for students and professionals, which highlights that in general it is an important strategic part in the creation of quality educational services. Based on the answers given by students from the two Universities, they appear to be influenced by a lack of personal motivation and an outdated curriculum offered to them, factors that contribute to their abandonment or commitment to their studies. Other factors such as the university environment and students' work commitments appear to be factors in student dropout but to a lesser extent for the two reasons cited above.

RQ5. Literature typically states that student retention is a concern for many higher education institutions and there are many techniques that can be used to increase it. While the literature provides data and information on employee satisfaction and its positive association with greater customer satisfaction, research has not examined various aspects of employee satisfaction and how they relate to various aspects of customer satisfaction. Finally, while employee satisfaction and customer satisfaction issues have been discussed in various organizational contexts, a large number of research studies on the university environment have not been identified. Concerning the Greek case, a study conducted by a team of researchers (Vergidis, et al., 2013) on leakage into learning and education structures, involving 481 people who had already abandoned education programs, was identified as the most important causes of The following are leaks: Occupational obligations, lack of time, family reasons, health reasons and exhaustive working hours. Such conclusions are reached by Houle (1964, cited in Vergidis, et al., 2013, p. 19), referring to issues related to learning objectives, to poor understanding of educational material, to personal / family problems on issues related to educational change itself, and on organizational issues. In conclusion, the research suggests that stakeholders have a great influence on decision making, both in the private and public sectors. In fact in the field of higher education it seems that the stakeholders are perhaps even more important and the different nature of the university's activities with many stakeholders needs to be considered. This is also reflected by Brookes (2003), who suggests that universities are a highly complex stakeholder environment and now operate as quasicommercial enterprises. The research highlights the importance of students, as they are by far the main "customers" of the university. However, it seems to be increasingly focused not only on these "clients" but also on those who influence them, such as academic colleagues.

\section{References}

1. Abdulsalam, D., \& Mawoli, M. A. (2012). Motivation and job performance of academic staff of state universities in Nigeria: the case of Ibrahim Badamasi Babangida University, Lapai, Niger State. International Journal of Business and management, 7(14), 142.

2. Agle, B., T. Donaldson, R. Freeman, M. Jensen, R. Mitchell, and D. Wood. 2008. 'Dialogue: Toward Superior Stakeholder Theory.' Business Ethics Quarterly 18(2), 155-190.

3. Asif, M., Awan, M. U., Khan, M. K., \& Ahmad, N. (2013). A model for total quality management in higher education. Quality \& Quantity, 47(4), 1883-1904.

4. Avram, E. M., \& Avram, R. M. (2011). Quality Management In Higher Education Institutions. Holistic Marketing Management Journal, 1(2), 41-47.

5. Baumgartner, J. and Jones, B. (1993) Agendas and Instability in American Politics, Chicago, IL:University of Chicago Press.

6. Beerkens, M. (2015). Quality assurance in the political context: in the midst of different expectations and conflicting goals. Quality in Higher Education, Vol 51(3), 231-250. Retrieved on 30 October, 2017 from http://www.tandfonline.com/doi/full/10.1080/13538322.2015 .1111004 .

7. Bone, Z., J. Crockett, and S. Hodge. (2006). Deliberation forums: a pathway for public participation. Paper presented at the APEN International Conference 2006,

8. Beechworth, Australia.

9. Bryson, J. (1995) Strategic Planning for Public \& Non-Profit Organisations (rev, edn), San Francisco, CA: Jossey-Bass.

10. Bryson, J. (2004) What to do when stakeholders matter. Public Management Review, 6(1). (Routledge). 
11. Bryman, A. and Bell, E. (2003) Business Research Methods (Oxford, Oxford University Press).

12. Chapleo, C., \& Simms, C. (2010). Stakeholder analysis in higher education: A case study of the University of Portsmouth. Perspectives, 14(1), 12-20.

13. Chen, S. H., Yang, C. C., Shiau, J. Y., \& Wang, H. H. (2006). The development of an employee satisfaction model for higher education. the TQM Magazine, 18(5), 484-500.

14. Clarkson, M. (1995) A stakeholder framework for analysing and evaluation corporate social performance. Academy of Management Review, 20, 92-117.

15. Denscombe, M. (2008). The Good Research Guide for smallscale social research projects (Third Edition). Maidenhead: McGraw-Hill Open University Press.

16. Donaldson, T. and Preston, L. (1995) The stakeholder theory of the corporation: Concepts, evidence, and implications. Academy of Management Review, 20(1), 65-91.

17. Douglas, J., Douglas, A., \& Barnes, B. (2006). Measuring student satisfaction at a UK university. Quality assurance in education, 14(3), 251-267.

18. Douglas, J., McClelland, R., \& Davies, J. (2008). The development of a conceptual model of student satisfaction with their experience in higher education. Quality assurance in education, 16(1), 19-35.

19. Drennan, L. T. (2000). Total quality management in higher education: an evaluation of the impact of assessment and audit on the quality of teaching and learning in the Scottish Universities (Doctoral dissertation, University of Glasgow).

20. Eden, C. and Ackermann, F. (1998). Making Strategy: The Journey of Strategic

21. Management. London: Sage Publications.

22. Emanuel, R., \& Adams, J. N. (2006). Assessing college student perceptions of instructor customer service via the Quality of Instructor Service to Students (QISS) Questionnaire. Assessment \& Evaluation in Higher Education, 31(5), 535-549.

23. Enz, C., Renaghan, L. M. and Geller, N. A. (1993) Graduatelevel education: A survey of stakeholders. Cornell Hotel and Restaurant Administration Quarterly, 34(4), 90-95.

24. Falasca, M. (2011). Barriers to adult learning: Bridging the gap. Australian Journal of Adult Learning, 51(3), 583-590.

25. Freeman, R.E. (1984) Strategic Management: A stakeholder approach. (Boston, MA, Pitman).

26. Gomes, R.C. and Gomes, L.O.M. (2009) Depicting the arena in which Brazilian local government authorities make decisions - what is the role of stakeholders?, Internbational Journal of Public Sector Management, Vol.22 No.2, pp.7690.

27. Hamshire, C., Forsyth, R., Bell, A., Benton, M., KellyLaubscher, R., Paxton, M., \& Wolfgramm-Foliiaki, E. (2017). The potential of student narratives to enhance quality in higher education, Quality in Higher Education, Vol 23(1), 50-64. Retrieved on 12 July, 2017 from http://wwwtandfonlinecom.proxy.eap.gr/doi/pdf/10.1080/13538322.2017.1294407.

28. Hennig-Thurau, T., Langer, M. F., \& Hansen, U. (2001). Modeling and managing student loyalty: An approach based on the concept of relationship quality. Journal of service research, 3(4), 331-344

29. Hillesheim, G. (1998). Distance learning: Barriers and strategies for students and faculty. The Internet and Higher Education, 1(1), 31-44.

30. Houle, C. O. (1964). Who Stays-and Why?. Adult Education, 14(4), 225-233.

31. Leiber, T., Stensaker, B., \& Harvey, L. (2015). Impact evaluation of quality assurance in higher education: methodology and causal designs. Quality in Higher Education, Vol 21(3), 288-311. Retrieved on 7 September, 2016 from http://www-tandfonlinecom.proxy.eap.gr/doi/pdf/10.1080/13538322.2015.1111007? needAccess=true.
32. LeNoue, M., Hall, T., \& Eighmy, M. A. (2011). Adult education and the social media revolution. Adult learning, 22(2), 4-12.

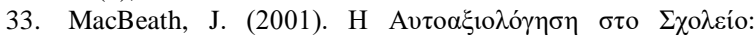

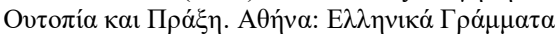

34. Maassen, P. (2000) The Changing Roles of Stakeholders in Dutch University Governance. European Journal of Education, 35(4), 449-464(16).

35. Margerum, R. (2002) Collaborative Planning: Building consensus and a distinct model of practice. Journal of Planning Education and Research, 21, 237-53.

36. Michaelson, S. J. (1994). Implementation of total quality management in an academic unit of a higher education institution.

37. Miles, M.B. and Huberman, A.M. (1994) Qualitative Data Analysis: An Expanded Sourcebook Thousand Oaks, CA: Sage, USA).

38. Mitchell, R., Agle, B. and Wood, D. (1997) Toward a Theory of Stakeholder Identification and Salience: Defining the Principle of Who and What Really Counts. Academy of Management Review, 22(4).

39. Mohammad Mosadegh Rad, A. (2006). The impact of organizational culture on the successful implementation of total quality management. the TQM Magazine, 18(6), 606625.

40. Moore, M. (1995) Creating Public Value, Cambridge, MA: Harvard Press.

41. Neville, B. and Menguc, B. (2006) Stakeholder Multiplicity: Toward an Understanding of the Interactions between Stakeholders. Journal of Business Ethics, 66, 377-391.

42. Nutt, P. C. \&. Backoff,. R. W. (1992). Strategic Management of Public and Third Sector Organizations: A Handbook for Leaders. San Francisco: Jossey-Bass.

43. Oliver, C. (1991) 'Strategic Responses to Institutional Processes', The Academy of Management Review, Vol. 16, No. 1 pp.145-179.

44. Perkins, J.A. (1973), The University as an Organization, McGraw-Hill, New York, NY

45. Polonsky, M. J. 1995. A Stakeholder Theory Approach to Designing Environmental Marketing Strategy. The Journal of Business \& Industrial Marketing 5(3): 29-46

46. Reed, M., Graves, A., Dandy, N., Posthumus, H., Hubacek, K., Morris, J., Prell, C., Quinn, C. and Stringer, L. (2009) Who's in and why? A typology of stakeholder analysis methods for natural resource management. Journal of environmental management, 90, 1933-1949.

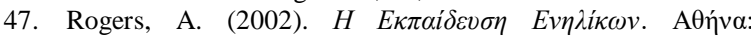

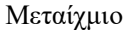

48. Rowley, T. (1997) 'Moving beyond dyadic ties: a network theory of stakeholder influences' The Academy of Management Review, Vol. 22, No. 4. pp.887-910.

49. Rumble, G. (2000). Student support in distance education in the 21st century: Learning from service management. Distance education, 21(2), 216-235.

50. Rust, C., Price, M., \& O'Donovan, B. (2003). Improving students' learning by developing their understanding of assessment criteria and processes. Assessment \& Evaluation in Higher Education, 28(2), 147-164. doi: 10.1080/02602930301671

51. Shanahan, P. and Gerber, R. (2004) Quality in university student administration: stakeholder conception. Quality Assurance in Education, 12(4), 166-174.

52. Shortell, S. M., O'Brien, J. L., Carman, J. M., Foster, R. W., Hughes, E. F., Boerstler, H., \& O'Connor, E. J. (1995). Assessing the impact of continuous quality improvement/total quality management: concept versus implementation. Health services research, 30(2), 377.

53. Stake, R.E. (1995) The art of case study research. (Thousand Oaks, CA, Sage)

54. Walker, E. A. (1999). Characteristics of the adult learner. The Diabetes Educator, 25(6_suppl), 16-24. 
55. Wang, Y. S. (2003). Assessment of learner satisfaction with asynchronous electronic learning systems. Information \& Management, 41(1), 75-86.

56. Wit, K. and Verhoeven, J. (2000) Stakeholders in Universities and Colleges in Flanders. European Journal of Education, 35(4).

57. World Bank (2007) How to Build M\&E Systems to Support Better Government http://siteresources.worldbank.org/EXTEVACAPDEV/Resou rces/4585672-1251737367684/How_to_build_ME_gov.pdf

58. UNICEF (2001) A UNICEF Guide for Monitoring and Evaluation, http://www.unicef.org/reseval/index.html

59. UNDP (2002) Handbook on Planning, Monitoring and Evaluating for Development Results, http://www.undp.org/eo/handbook

\section{Greek}

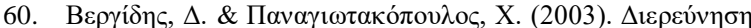

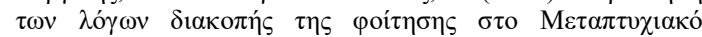

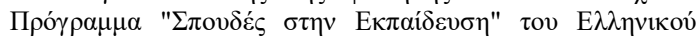

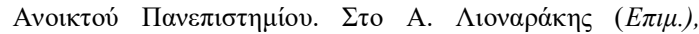

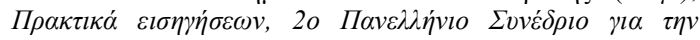

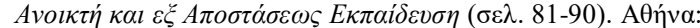
Пролонло́s

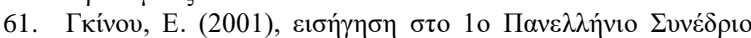

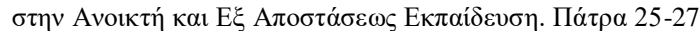
Maíov 2001

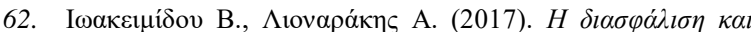

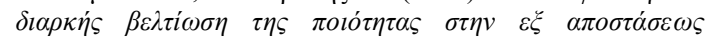

$\pi \alpha v \varepsilon \pi \imath \sigma \tau \eta \mu \imath \alpha \kappa \dot{~ \varepsilon \kappa \pi \alpha i ́ \delta \varepsilon v \sigma \eta . ~ T \alpha ́ \sigma \varepsilon ı \varsigma ~ \kappa \alpha l ~ \pi \rho o \sigma \alpha v \alpha \tau o \lambda ı \sigma \mu o i ́, ~ T h e ~}$ Journal of Open and Education and Educational Technology,

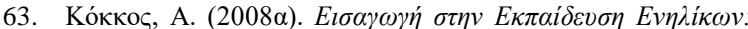

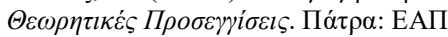

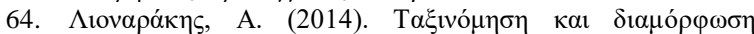

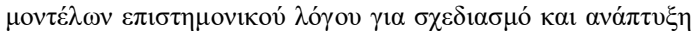

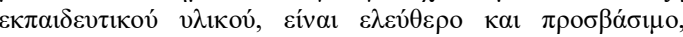
hyperlink: https://www.slideshare.net/antonislionarakis, Тон.13, Ар.2

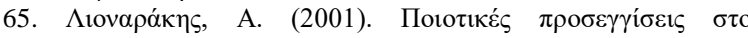

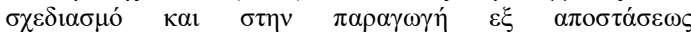

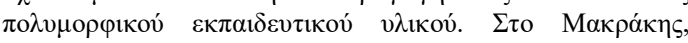

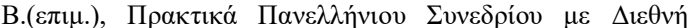

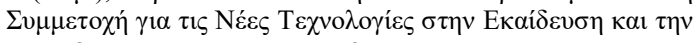

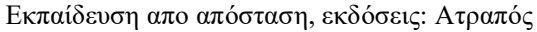

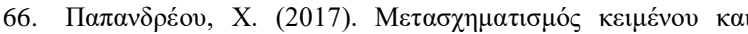

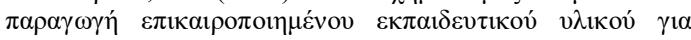

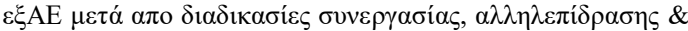

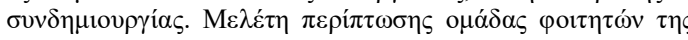

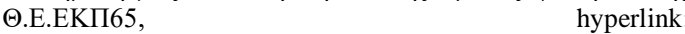
http://eproceedings.epublishing.ekt.gr/index.php/openedu/arti cle/view/1038/0

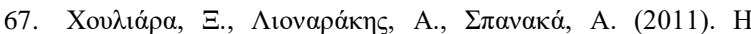

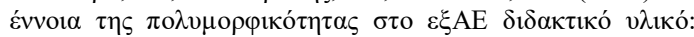

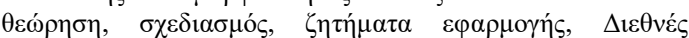

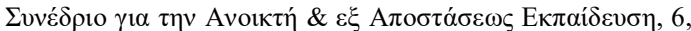

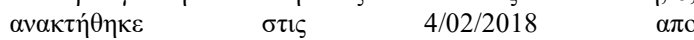
http://dx.doi.org/10.12681/icodl.767 